\title{
Spis gazet polskich
}

okresu międzywojennego (1918-1939) w Bibliotece Uniwersyteckiej w Poznaniu

STRESzCzenie. Informacja dotyczy retrospektywnej bazy gazet, dzienników i orędowników w wersji on-line znajdujących się w Bibliotece Uniwersyteckiej w Poznaniu. Baza gazet wydawanych w języku polskim obejmuje okres międzywojenny 1918-1939. Spisu gazet i roczników dokonano z autopsji.

SŁowA KLUCzowe: gazety polskie, baza gazet

Od 19 do 21 października 2006 roku odbyła się w Poznaniu międzynarodowa konferencja zorganizowana przez Bibliotekę Uniwersytecką w Poznaniu, Wyższą Szkołę Umiejętności Społecznych w Poznaniu oraz IFLA Newspapers Section, poświęcona gazetom, ich zasobom, opracowaniu, ochronie, promocji, digitalizacji i informacji. Przedmiotem badań były gazety w aspekcie historycznym i współczesnym.

Jeden z referatów konferencji dotyczył zasobów gazet Drugiej Rzeczypospolitej Polskiej zgromadzonych w Bibliotece Uniwersyteckiej w Poznaniu $^{1}$. Kontynuacją rozpoczętych prac było porównanie stanu faktycznego tytułów i zasobów w magazynach z informacją o nich w katalogu kartkowym BU. W efekcie tych działań stworzono retrospektywną bazę gazet i dzienników w wersji on-line. Baza obejmuje gazety, dzienniki i orędowniki o zasięgu chronologicznym 1918-1939, wydawane w języku polskim

${ }^{1}$ B. Góra, Gazety polskie okresu międzywojennego w Bibliotece Uniwersyteckiej w Poznaniu, w: Gazety: zasoby, opracowanie, ochrona, digitalizacja, promocja/informacja. Materiaty z międzynarodowej konferencji naukowej, 19-21 października 2006, red. A. Jazdon, A. Chachlikowska, Poznań 2006. 
na terenie Polski, ukazujące się z częstotliwością od dwóch do siedmiu razy w tygodniu. Zestawienie tytułów powstało również na podstawie katalogów bibliotecznych, bibliografii, baz on-line Biblioteki Narodowej (Centralny Katalog Czasopism Polskich - CKCZP) i zestawienia tytułów gazet sporządzonych przez Darię Nałęcz i Władysława Władykę².

Można stwierdzić, że w katalogach on-line polskich bibliotek brak jest tytułów gazet i dzienników z XIX i XX wieku. Przede wszystkim opracowuje się czasopisma retro o mniejszych formatach. Poszukiwanie gazet w katalogach jest duże - z tego też między innymi powodu zadecydowano o utworzeniu takiej bazy. Uzupełni ona z pewnością bibliografię czasopism polskich, określając liczbę wydanych tytułów i liczbę zachowanych roczników.

„Spis gazet polskich okresu międzywojennego (1918-1939) w Bibliotece Uniwersyteckiej" umieszczony na stronie domowej Biblioteki zawiera 472 tytuły gazet, dzienników i orędowników. Wliczenie do spisu orędowników (129) okazało się konieczne. Mimo że są one pismami zasadniczo urzędowymi, to zawierają pełen serwis agencyjno-informacyjny, typowy dla prasy codziennej z uwzględnieniem wiadomości lokalnych. Bazę „Spis gazet polskich..." można przeszukać według następujących indeksów: tytuł, sygnatura, miejsce wydania i rok wydania. Zasoby BU-UAM, które rejestruje spis, nie zawsze pokrywają się z datami ich wydania, są niekompletne, czasami jednak w spisie znajdziemy więcej roczników danego tytułu niż w bazie BN CKCZP. W wielu przypadkach z uwagi na szczątkowy zasób trudno było ustalić daty wydania.

Aby uzyskać najbardziej aktualny spis, wszystkie tytuły sprawdzono w magazynie. Organizacja tego typu przedsięwzięcia stwarzała pewne trudności (format IV i V, duża liczba roczników w obrębie tytułu). Praca ta jednak przyniosła wymierne efekty. Przede wszystkim uporządkowano gazety z okresu dwudziestolecia ubiegłego wieku, które do zbiorów wpłynęły jako egzemplarze obowiązkowe, jako dary lub kupno. Zasadniczo, co należy podkreślić, „konfrontacja” wypadła pomyślnie, ponieważ tytuły i zasoby gazet w katalogu kartkowym pokrywają się ze stanem magazynowym. Okazało się, że tylko niektóre tytuły są zagubione, inne nie były przedtem notowane w katalogu BU i w różnych innych spisach. Było to spowodowane zmieniającymi się tytułami w obrębie zasobów. Kolejny

${ }^{2}$ D. Nałęcz, Gazety ukazujace się 2-4 razy w tygodniu w Polsce w latach 1919-1939. Zestaw tytułów i charakterystyka statystyczna, „Kwartalnik Historii Prasy Polskiej” 1978, t. 17, z. 2, s. 96-110; W. Władyka, Dzienniki w jezyku polskim w Drugiej Rzeczypospolitej (1918-1939). Zestaw tytułów, „Rocznik Historii Czasopiśmiennictwa Polskiego” 1975, t. 14 , z. 4 , s. $495-527$. 
plus to przeprowadzenie selekcji, scalenie dwóch niekompletnych ciągów egzemplarzy w jeden, stwierdzenie zagubień, co pozwoliło Sekcji Skontrum poczynić dalsze prace porządkujące. Większość gazet jest w dobrym stanie, są starannie oprawione i zachowane mimo upływu lat. Niektóre z nich charakteryzowały się krótkim okresem wydawania; niekiedy zasób ograniczał się do kilku numerów.

W spisie gazet zrezygnowano z wyszczególniania numerów w obrębie roczników. Uwzględniono tylko zasoby kumulacyjne. Należy pamiętać, że gazety były wydane na kwaśnym papierze. Ich kartkowanie powoduje degradację zbiorów, stąd konieczna staje się ich digitalizacja.

Niektóre tytuły - z pełnym zasobem - są już opracowane w bazie Horizon. Tam czytelnik znajdzie cały zasób mieszczący się w BU.

Co daje baza? Dlaczego warto ją promować? Komu będzie przydatna? Baza gazet (1918-1939) jest bogatym i klarownym zestawieniem tytułów gazet, dzienników i orędowników Drugiej Rzeczypospolitej Polskiej. Uwzględnia też tytuły i zasoby zgromadzone w BU-UAM przed rokiem 1918.

Bibliografia on-line zamieszczona w Internecie ma uzupełniać istniejące tego typu spisy i bibliografie drukowane. Można sięgnąć do niej bezpośrednio i uzyskać informacje o tym, czy poszukiwany przez nas tytuł znajduje się w bazie. „Spis gazet polskich...” to propozycja współpracy dla wszystkich instytucji, które szukają brakujących tytułów w celu uzupełnienia własnych zbiorów. BU zgodnie ze swoją polityką gromadzenia jest otwarta na wszelką wymianę tytułów z innymi placówkami naukowymi i instytucjami kultury.

Spis gazet (1918-1939) BU i ich zasobów ma być pomocnym, aktualnym i przydatnym spisem gazet polskich z tego okresu dla bibliotek, archiwów, muzeów i badaczy prasy polskiej XX wieku. Celem powstania bazy prasy polskiej, będącej naszym dziedzictwem narodowym, jest jej digitalizacja.

Dzięki wymianie i współpracy baza będzie na bieżąco aktualizowana. Umieszczenie informacji o prasie codziennej z międzywojnia XX wieku na platformach cyfrowych to, z jednej strony, jej promocja, z drugiej - zapewnienie ochrony i rzetelności przekazu. 


\section{BARBARA GÓRA, ALEKSANDRA MIKOŁAJSKA}

\section{A list of Polish newspapers from the interwar period (1918-1939) at Poznań University Library}

Aвstract. This brief information provides a description of a retrospective online database of newspapers, daily publications and official bulletins and publications available at Poznań University Library. The database of newspapers published in the Polish language encompasses publications from the interwar period, i.e. the years 1918-1939. The list has been prepared from personal inspection.

KEY wORDs: Polish newspapers, newspaper database 